\title{
PERCEPTION OF THE LEXEME 'EUROPE’ BY STUDENTS: A PSYCHOLINGUISTIC ANALYSIS
}

\author{
Iryna Postolova \\ postolova.i@gmail.com \\ Nataliia Tomarieva \\ tomarev17@gmail.com \\ National University of Pharmacy, Ukraine
}

Received May 4, 2018; Revised June 28, 2018; Accepted June 29, 2018

\begin{abstract}
The article analyzes the results of the free associative experiment, which was conducted among first-year students during 2016-2018. According to the frequency of reactions, the authors model the structure of the associative field: nucleus, body and periphery; define the morphological and semantic groups of associations on the word-stimulus 'Europe' obtained during the experiment, analyze the syntagmatic and paradigmatic relationships among the reactions, build the structure of the resulting associative field. The responses of respondents are significantly dominated by nouns; occasionally occur adjectives, verbs, adverbs and pronouns; adjectives and adverbs are mostly colored with emotions and estimations. Phrases make a significant group of associations phrases (about one fifth). Among the above mentioned things, toponyms and surnames of well-known political figures are named. Semantically, all as sociations are divided in general cultural, economic and political, such ones that express aesthetic perception of the word-stimulus, as well as those related to travel and leisure. Special attention in the article is given to emotional coloring of reactions (they are divided in positive, negative and neutral). Thus, the material presented in the work reflects, to a certain extent, the perception of the wordstimulus 'Europe' by contemporary student youth.
\end{abstract}

Keywords: psycholinguistics, associative experiment, word-stimulus "Europe”, reaction, perception.

Постолова Ірина, Томарєва Наталія. Сприйняття лексеми “Свропа” студентами: психолінгв істичний аналіз.

Анотація. У статті проаналізовано результати вільного асоціативного експерименту, який було проведено серед студентів першого курсу протягом 2016-2018 років. 3 огляду на частотність реакцій, автори моделюють структуру ассоціативного поля: ядро, тіло та периферію; виділяють морфологічні та семантичні групи асоциацій на слово-стимул “Свропа", отриманих під час експерименту, аналізують синтагматичні та парадигматичні зв'язки між реакціями, вибудовують структуру отриманого асоціативного поля. У відповідях респондентів значно переважають іменники, зрідка зустрічаються прикметники, дієслова, прислівники та займенники, причому прикметники та прислівники здебільшого емоційно та оціночно забарвлені. Значну групу ассоціацій становлять словосполучення (приблизно п’яту частину). Серед іншого були названі топоніми та прізвища відомих політичних фігур. Семантично асоціації поділяються на загальнокультурні, економікополітичні, ті, що виражають естетичне сприйняття слова-стимулу, а також ті, що повязані 3 подорожами та відпочинком. Емоційному забарвленню реакцій у статті приділено особливу увагу (вони поділяються на позитивні, негативні та нейтральні). Отже, представлений у

(C) Postolova, Iryna; Tomarieva, Nataliia, 2018. This is an Open Access article distributed under the terms and conditions of the Creative Commons Attribution 4.0 International Licence (http://creativecommons.org/licenses/by/4.0).

East European Journal of Psycholinguistics, 5(1), 36-44. https://doi.org/10.5281/zenodo.1436356 
роботі матеріал у певній мірі відображає сприйняття лексеми “Європа” сучасної студентською молоддю.

Ключові слова: психолінгвістика, асочіативний експеримент, слово-стимул “Свропа”, реакція, сприйняття.

\section{Introduction}

The path to European integration is of great importance to the history of the modern Ukrainian state, which from time to time causes wide public and political discussions, including those among young people. In such circumstances, it is worth paying attention to the results of the psycholinguistic experiment with the word stimulus 'Europe' among the student audience. Moreover, one should mention that, so far, there is no such word-stimulus in Ukrainian (Butenko, 1979; 1989; Voitko, 1978; Martinek, 2008), and Russian (Leontyev, 1973; Ufimtseva, 2004; Cherkasova, 2008) associative dictionaries. The political aspect of "Europe" was considered in research of Ukrainian scientist prof. Zhabotinska (Zhabotinskaya, 2015), but our task was to broaden and deepen the context of the word-stimulus, describing it comprehensively.

\section{Methods}

The research was carried out with the help of free association method, which appears to be one of the most efficient tools of linguistic conscience research in small social groups (Goroshko, 2001).

2.1. Procedure. During the period of 2016-2018, 264 respondents (age 17-18, $85 \%$ women, $15 \%$ men) participated in the psycholinguistic experiment. Participants of it were asked to record the first associations on the specified lexeme "Europe" within one minute (time was the only restriction for the participants). The result was 975 reactions, of which 494 were not repetitive (353 words, 141 phrases and 1 image), 17 students refused to answer.

The classification of the results obtained during free associative experiment is always a particular difficulty. As known, “... the problem of classification of associations exists as long as the theory of associations itself, because when one works with associative material, naturally arises the problem of its certain differentiation..." (Goroshko, 2001).

Nowadays, there are dozens of classifications of associative material, but "the problem of its high-quality analysis hasn't been completely solved yet, and the construction of some ideal classification of associations based on a certain consistent principle is neither possible, nor necessary" (Goroshko, 2001). At the same time, "the analys is of the associations themselves often helps to clarify and formalize the allocated classes, i.e. the process of reaction analysis and the one of construction of classification can develop in both directions: from classification to reaction and backwards, from reaction to classification (Ershova, 1998)" (Goroshko, 2001).

In our work, we applied elements of various classifications, including such of H. Munsterberg, B. Bourdon, R. Woodworth, K. Grigoryan, N. Gasitsa, T. So- 
kolova, S. Sabitova, E. Ivanova, T. Yershova, Yu. Karaulov and A. Novikova. Thus, we used:

- classification of reactions by frequency;

- extraction of nucleus and periphery of associative field;

- classification by parts of speech;

- identification of the synthagmatic and paradigmatic connections between the word-stimulus and the reactions;

- separation of the semantic groups of associations;

- identification of evaluative and personal responses;

- separation of associations according to the emotional characteristics.

\section{Results and Discussion}

The distribution of the received associations according to the frequency of references allowed to form the associative field of the experiment, in which to allocate respectively core, body and periphery (singular references). The most frequent reactions are travel (podorozh / podorozhi / puteshestvye / puteshestvyya in total 56 times), country (krayina / krayiny / strana / strany 34 times in total), rest (vidpochynok / otdykh 25 times), Ukraine (Ukrayina / Ukrayna 25 times). In this way, we see that the young people clearly associate our country with Europe and also see for themselves the opportunity to travel and relax in European cities.

To count the reactions, which form the body of the association field, were taken the reactions with frequency of at least three time itineration, such as: beauty (total 17 records) (krasota (16) / krasa), culture (17) (kul'tura), money / money (14) / money (euro) (16 total records) (groshi / den'gi (14) / den'gi (yevro)), Paris (16) (Parizh), work (total 16 references) (rabota (12) /robota (4)), development (total 15 references) (razvitiye (11) / rozvitok (4)), EU (14), people (13) (lyudi), France (13), opportunities (10) / opportunity (total 11 records) (vozmozhnosti (8) / mozhlivostí (2) / mozhlivist'), Germany (11), the European Union (11), euro (10) (evro), beautiful (10) (krasivo), politics (9) (politika), large (total 8 reactions) (bolshaya (5)/ velika (3)), Italy (8) (Italiya), Poland (total 8 reactions) (Polsha (7)/Polscha), plane (total 8 reactions) (samolet (7)/litak), cleanness (8) (chistota), good life (total 7 reactions) (harne zhittya/horoshaya zhizn (6)), war (6) (voyna), sights (6) (dostoprimechatelnosti), future (total 6 reactions) (buduschee (5)/majbutne), language/languages (total 6 reactions) (mova (2) / yazyik (3) / yazyiki), English (total 5 reactions) (angliyska/angliyskiy (2)/angliyskiy yazyik (2)), England (5) (Angliya), visa (5) (viza), law/laws (total 5 reactions) (zakon (2) / zakonyi (3)), Spain (total 5 reactions) (Ispaniya (4) / Ispaniya (Madrid)), dream (5) (mechta), world (5) (mir), sea (5) (more), order (5) (poryadok), freedom (5) (svoboda), architecture (4) (arhitektura), more opportunities (2) / great opportunities (2) (total 4 reactions) (bolshe vozmozhnostey (2) / bolshie vozmozhnosti (2)), large salary / salary / high salary / high salaries (total 4 reactions) (bolshaya zarplata / visoki zarplati / vyisokaya zarplata / vyisokie zarplatyi), expensive (4) (dorogo), west (4) (zapad), maydan (4) (maydan), flag/flags (total 4 reactions) (prapor/ 
prapori/flag/flagi), interesting (total 4 reactions) (interesno (3)/tsikavo), Angela Merkel/Merkel (2), globe (3) (globus), friends (3) (druzya), excursion/ excursions (total 3 reactions) (ekskursiyi / ekskursiya / ekskursii), life (3) (zhizn), abroad (3) (zagranitsa), foreigners (3) (inostrantsyi), fashion (3) (moda), NATO (3), education (obrazovanie/osvita (2)), passport (3) (zagranpasport (2)/pasport zagran), perspective (3) (perspektiva), adventure(2)/adventures (priklyuchenie(2)/ priklyucheniya), problems (3) / (problemi (2)/problemyi), Russia (3) (Rossiya) etc.; the reactions with more than tree time itinerary formed the periphery - refugees (2), visa-free regime (2), Eurovision (2), continent (2), UN (2), prestigious (2), Glory to Ukraine! (2), tolerance (2), standard of living (2), Americans, without bribes, carefree, prosperity, delirium, will be bad for Ukraine, Warsaw, forward, universe, high prices, Hitler, homosexuality, dirt, mystery, catastrophe, comfort, corruption, loans, crisis, love, shops, musicians, the best universities, we do not need there, German sausages, not ours, unidentified, Obama, deception, burden, gay marriage, box, beer, pizza, planet, Beaches, political issues, human rights, Putin, equality, resources for use, self-realization, with Ukraine's aspirations for the better, but useless, difficult life, stupid stereotypes, tourist, luck, successful investments, Ukraine is Europe, Ukraine is far from being Europe, improvement, fjords, a part of the world, in 10 years, clean streets, something incomprehensible, a step forward, the elite, emotions, etc.

As the next step of our research we have identified morphological groups of reactions (nouns $-757 / 310$, adjectives $-28 / 19$, adverbs $-30 / 15$, verbs $-9 / 8$, as well as separate pronouns $-3 / 3$ and numerous phrases $-161 / 141$; the first number shows general quantity of reactions, the second one - quantity of singular reactions). The respondents have chosen in overwhelming majority paradigmatic reactions (wordsreactions of the same grammatical class, as well as a word-stimulus). Syntagmatic associations (words-reactions refer to other grammatical class, rather than a wordstimulus) are seldom. This fact testifies to domination of language associations over speech ones. The experiment results are visually represented with the following diagrams:

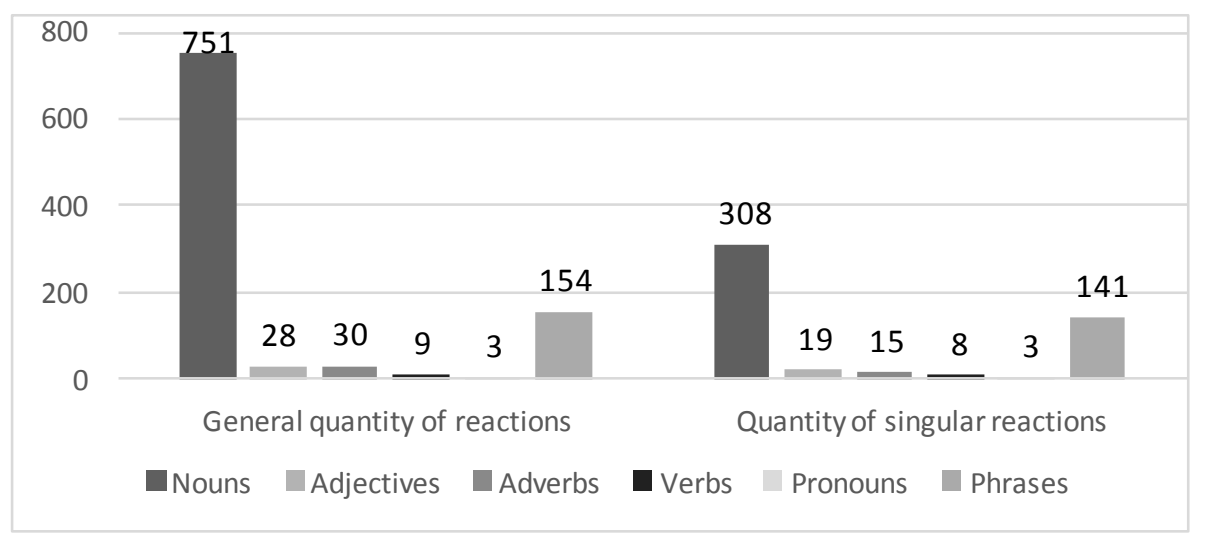

Fig. 1. Morphological groups of reactions 


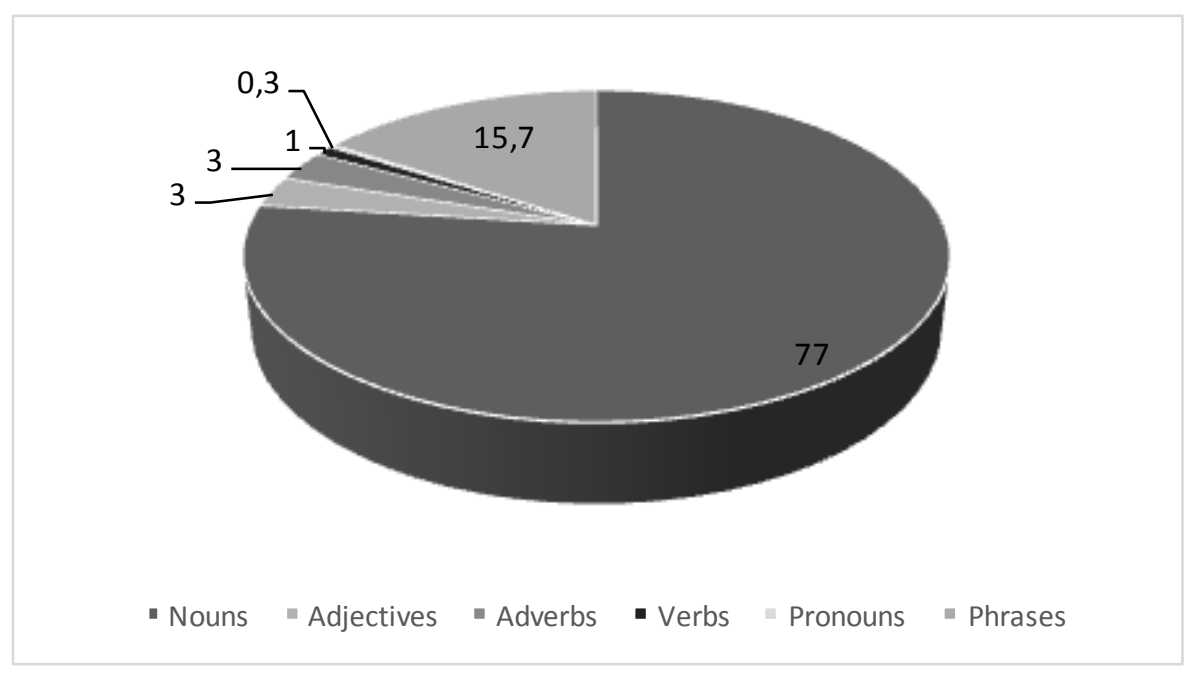

Fig. 2. Morphological groups of reactions (per cent)

In total paradigmatic reactions make $77 \%$, syntagmatic ones $-23 \%$ that testifies the high level of actualization of a word-reaction in associative process.

The most part of reactions was mentioned during description of associative field structure. Among the nouns mentioned above, there is a separate group of proper names (36 geographic names (Germany (Nimechchyna), Paris (Paryzh), Poland (Pol'shcha), Mediterranean Sea (Seredzemne more)) and 4 names of famous persons (Angela Merkel, Hitler, Putin, Obama). As for adjectives and adverbs, they are in majority, both emotional and estimative: rich (2) (bogataya), big (5) (bolshaya), great (3) (velika), mysterious (zagadochnoe), exciting (zahoplyuyucha), beautiful (krasiva), cultural (kulturnaya), populous (mnogolyudnaya), unidentified (neopoznannoe), new (novoe), advanced (prodvinutaya), developed (razvitaya), relatives (2) (rodnyie), strong (silnaya), interesting (tsikawa), clean (chista), forward (vpered), expensive (4) (dorogo), interesting (3) (interesno), beautifully (10) (krasivo), colorful (krasochno), better (luchshe), much (mnogo), unjustifiably (neopravdanno), uncertainly (neopredelenno), perspectively (perspektivno), prestigious (2) (prestizhno), simply (prosto), entertaining (uvlekatelno).

The sparse verbs, which can be found in the reactions, are connected with motion and desire: not needed (ne nuzhny), I will go (poyedu), to discover (poznavat'), to travel (puteshestvovat'), we strive (stremimsya), it feels like (khochetsya), I want (2) (khochu), to read (chitat'). The pronouns are represented by the $1^{\text {st }}$ person plural that points out to the personal perception of this lexeme: we (my), not us (ne my), not ours (ne nashe).

Approximately the fifth part of all abovementioned reactions is represented by the phrases (161/141), the majority of which is an attempt to express personal attitude of the participants. The most typical for such phrases are nouns: opportunity/opportunities, development, salary/salaries, prices, association/ combination, urge, part; adjectives: big (bolshaya/ bolshie/ bolshiy /bolshie), high (vyisokayal vyisokiy/ vyisokie), good (harnel horoshayal horoshie), cheep (deshevyie), other (drugayal drugiel drugoel drugoy/ inshiy), European 
(evropeyskayal evropeyskie), law-obedient (zakonoposlushnyie), interesting (interesnyie), beautiful (krasivayal krasivyie), better (kraschil luchshayal naykraschi), new (novi/ novyie), developed (razvityiel rozvinuti), different (raznyie); adverbs: much, more, badly, well, a lot of and verbs: we will be, we want/ I want.

It is interesting to consider the reactions received from the point of view of their emotional coloring: there are positive ones (beauty (krasota), culture (kul $\square$ tura), standard of living (uroven - zhyzny), development (rozvytok), etc.), negative (war (voyna), expensive (doroho), migrants (myhranty), problems (problemy), homosexuality (homoseksualyzm), etc.) and neutral answers (European Union (Yevrosoyuz), Euro (Yevro), museum (muzey), people (lyudy), etc.) (Postolova, 2017). The number of positive (about 46\%) and neutral (about $45 \%$ ) associations significantly exceeds the number of negative associations (about $8 \%$ ). Interestingly enough, most negative associations are indicated in Russian, and among the positive-neutral associations Russian and Ukrainian languages are equally distributed. The topic looks rather painful for some of the respondents, hence the significant percentage of refusals, emotional responses and even one longfinger image response as an expression of extreme reflection. While analyzing the answers, it is impossible not to notice the strong influence of mass media, especially in the negative aspect: gays, same-sex marriages, homosexuality, crisis, loans, gas, Russia, Putin, refugees, migrants, political problems, etc. Despite the conditions of the experiment, many respondents seem not to give one-word association, but try to give arguments to a conventional opponent: no, early; we do not need there; not ours; Ukraine's aspirations for the better, but in vain, etc. Among positively-colored reactions, there are also such ones that were introduced from the outside and which are far from real perception: everything is good, a better life, miracles, the ideal, etc. Nevertheless, most of the received responses are positively neutral (the most frequent reactions are "travel" and "rest") and associate the word-stimulus with Ukraine (this reaction is included in the core of the associative field).

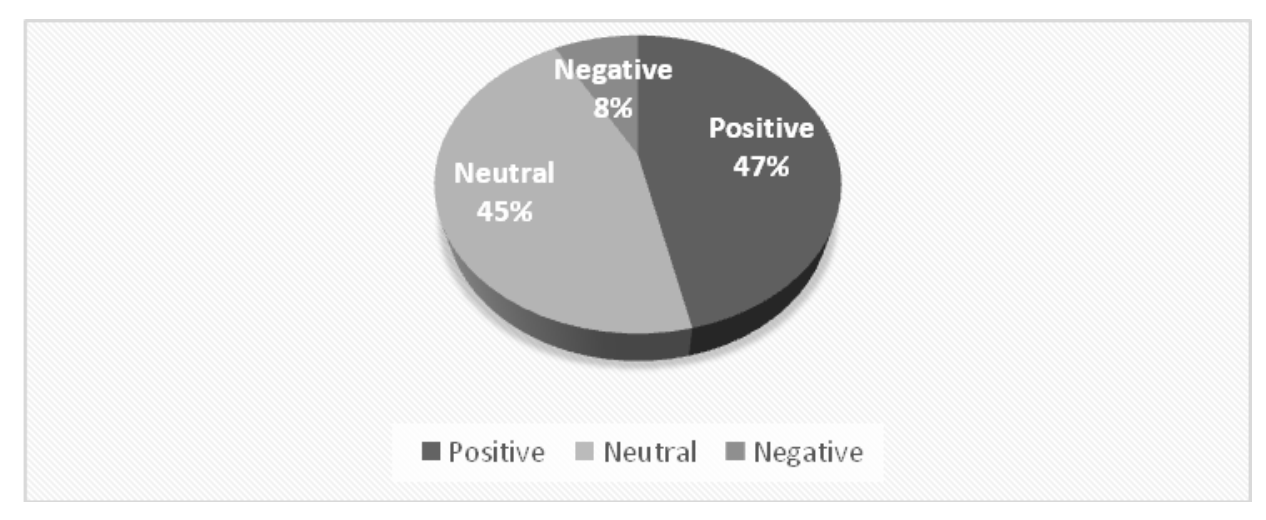

Fig. 3. Emotional coloring of reactions (per cent)

In general, among the resulting associations, there are several semantic groups, namely: proper names and names of persons, general cultural associations, social political associations, as well as travel/leisure and aesthetic ones. 
The group of proper names and names of persons includes 129 repetitive geographic names (Germany (Nimechchyna), Paris (Paryzh), Poland (Pol'shcha), Mediterranean Sea (Seredzemne more)) and 8 repetitive names of persons (Angela Merkel, Hitler, Putin, Obama) that makes $17 \%$ of total number.

To the general cultural associations we included the following: country (strana/strany/krayina/krayiny), culture (kul'tura), people (lyudy), European Union (Yevrosoyuz), Euro (Yevro), big (bol'shaya/velyka), sights (dostoprymechatel'nosty), language (movalyazyk/yazyky), English (anhliys'kal anhlyyskyy/ anhlyyskyy yazyk), architecture (arkhytektural arkhitektura), city (horod/horoda), west (zapad), many countries (mnogo stran), foreign (zahranytsa), foreigners (ynostrantsy), megacities (mehapolys) (31\% - the biggest group of reactions).

The considerable part of the received reactions $(24 \%)$ concerns the economic and political spheres: money (euro) (16) (den'gi), work (16) (rabota), development (15) (razvitie), opportunities (11) (vozmozhnosti), politics (9) (politika), war (6) (voyna), visa (5) (viza), law (5) (zakon), peace (5) (mir), order (5) (poryadok), freedom (5) (svoboda), expensive (4) (dorogo), maydan (4) (maydan), NATO (3), problems (3) (problemyi), refugees (2) (bezhentsyi), visa-free regime (2) (bezviz).

Among the total number of reactions, one can find the group travel and leisure $(15,5 \%)$. So, the travel association is mentioned during the experiment most often -56 times. In addition, the group includes the following semantic reactions as rest (25), airplane (8), sea (5), nature (4), excursion (3), adventure (3), resort, new people, gallop across Europe, holidays.

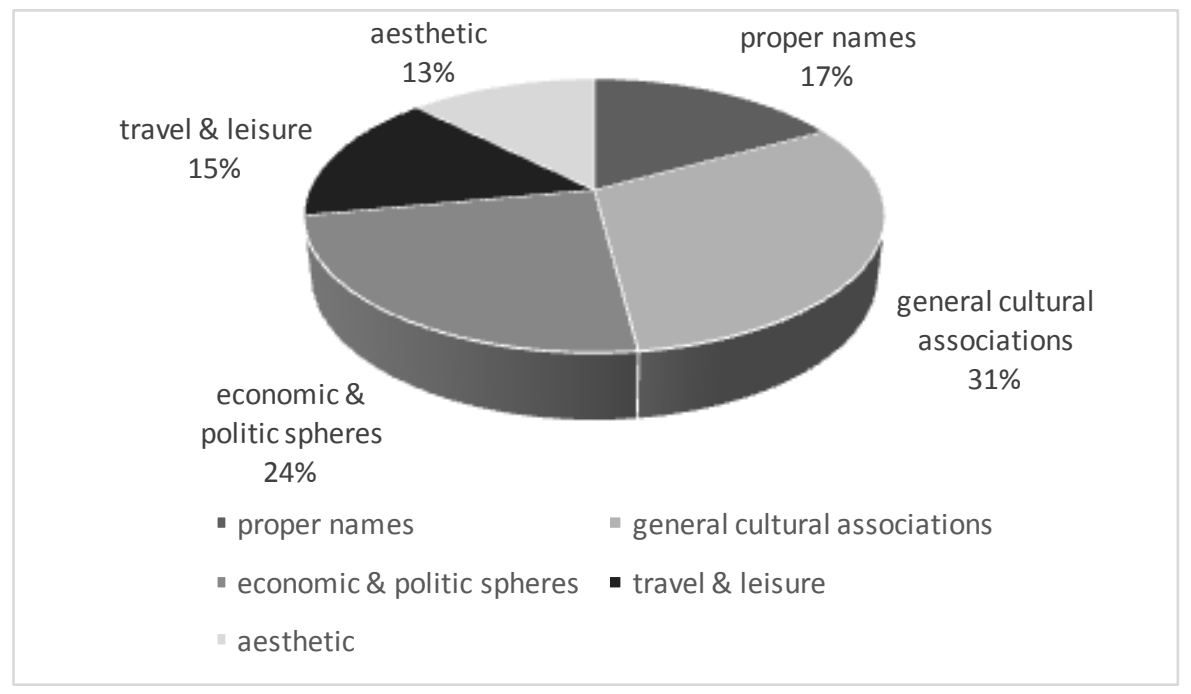

Fig. 4. Semantic distribution of reactions (per cent)

The group of associations, which can be called aesthetic, has brought some students' perception of Europe as the destination in which it is worth / not worth moving forward. It is represented by $12.5 \%$ of all reactions. It is a separate issue if, so far, these representations are based on real information or only on imposed stereotypes. The following associations are attributed to this group: beauty (17) 
(krasota), purity (8) (chistota), good life (7) (horoshaya zhizn'), future (6) (buduschee), dream (5) (mechta), carelessness (bezzabotnost'), nonsense (absurdnost'), wandering life (brodyachaya zhizn), it will be bad for Ukraine (Ukraine budet ploho), dirt (gryaz'), the door to a new, unexplored world that will bring both good and bad (dver'v novyiy neizvedannyiy mir, kotoryiy prineset kak horoshee, tak i plohoe). Semantic distribution of reactions is presented in Fig. 4.

Thus, from the available semantic groups, the group of general cultural associations is in the lead that is logical and predictable. The second by quantity is the group of economic and political sphere associations. Although there are fewer associations in the travel and leisure group, it is here that the most frequently mentioned reactions are presented. The fourth group of aesthetic associations is also represented quite widely, which does not allow us to consider it insignificant.

\section{Conclusions}

The experiment has given an opportunity to see the students' perception of Europe as a positive and attractive place for recreation and travel. These young people feel quite mobile, involved in a pan-European context. At the same time, all respondents are greatly influenced by mass media, and the word 'Europe' evokes a lot of their emotions and associations which are associated with the civilizational choice for Ukraine. Often, there is an opposition between Europe and Russia, which is caused, taking into consideration the events in the Eastern Ukraine, which we have been observing for four years already. From this point of view, it would be interesting to pay attention to the geography of the respondents, but since the research was anonymous, we were deprived of such an opportunity. In general, the positively colored reactions prevail, although some of them may be weakly correlated with the reality, being either dreams or fantasies. It is typical that many respondents do not divide Europe into components, for them this is indivisible, although, as we know, there are a lot of differences among particular European countries. It is worth pointing out that of the few word-stimuli which the experiment was conducted with, only this one received a significant number of rejections. Such a reaction may indicate a certain painfulness of the context of this concept for individual respondents. The social \& political sphere does not dominate, but is significant; there are many stereotypes in this group of answers, both with a positive and with a negative attitude.

\section{References}

Горошко Е. Интегративная модель свободного ассоциативного эксперимента. Харьков: Изд. группа "РА - Каравелла", 2001.

Postolova, I., Tomarieva, N. (2017). Emotional Aspects of Psycholinguistic Experiment with "Europe" as a word-stimulus. Third International Conference Challenges of Psycholinguistics and Psychology of Language and Speech COPAPOLS 2017. Book of Abstracts (77-78). Lutsk: Les ya Ukrainka Eastern European National University.

Жаботинская С. Язык как оружие в войне мировоззрений. МАЙДАН- АНТИМАЙДАН: словарь-тезаурус лексических инноваций. Украина, декабрь 2013 - декабрь 2014. Retrieved from: http://uaclip.at.ua/zhabotinskaja-jazyk_kak_oruzhie.pdf 


\section{References (translated and transliterated)}

Goroshko, E. Integrativnaya model svobodnogo assotsiativnogo eksperimenta [Integrational model of free associative experiment]. Kharkiv: RA-Karavella, 2001.

Postolova, I., Tomarieva, N. (2017). Emotional Aspects of Psycholinguistic Experiment with "Europe" as a word-stimulus. Third International Conference Challenges of Psycholinguistics and Psychology of Language and Speech COPAPOLS 2017. Book of Abstracts (77-78). Lutsk: Lesya Ukrainka Eastern European National University.

Zhabotinskaya, S. Yazyk kak Oruzhiye v Voyne Mirovozzreniy. MAIDAN-ANTIMAIDAN: Slovar-Tezaurus Leksicheskikh Innovatsiy. Ukraina, dekabr 2013 - dekabr 2014 [Language as a Weapon in the War of Worldviews. MAIDAN- ANTIMAIDAN: Dictionary-Thesaurus of Lexical Innovations. Ukraine, December 2013 - December 2014] Retrieved from: http://uaclip.at.ua/zhabotinskaja-jazyk_kak_oruzhie.pdf

\section{Джерела}

Асоціативний експеримент. Короткий психологічний словник / за ред. В. Войтко. Київ: Вища школа, 1978.

Бутенко Н. Словник асоціативних норм української мови. Льв ів : Вища школа, 1979.

Бутенко Н. Словник асоціативних означень іменників в українській мові. Львів: Вища школа, 1989.

Мартінек С. Український асоц іативний словник: У 2 т. 2 -ге вид. Львів: Паїс, 2008.

Славянский ассоциативный словарь: русский, белорусский, болгарский, украинский / под ред. Н. Уфимцевой. М., 2004.

Словарь ассоциативных норм русского языка. Прямой / под ред. А. Леонтьева. М., 1973.

Черкасова Г. Русский сопоставительный ассоциативный словарь. М.: ИЯ РАН, 2008.

\section{Sources}

Asotsiativniy eksperiment [Associative experiment]. (1978). Korotkiy Psykhologichnyi Slovnyk [Short Psychological Dictionary]. V. Voytko, Ed. Kyiv: Vyscha Shkola.

Butenko, N. (1979). Slovnik Asotsiativnykh Norm Ukrayinskoyi Movy [Associative Dictionary of the Ukrainian language]. Lviv: Vyscha Shkola.

Butenko, N. (1989). Slovnyk Asotsiativnykh Oznachen Imennykiv v Ukrayinskiy Movi [Dictionary of Associative Noun Attributes in the Ukrainian Language]. Lviv: Vischa shkola, 1989.

Martinek, S. Ukrayinskyi Asotsiativnyi Slovnyk [Ukrainian Associative Dictionary]: in 2 Volumes. $2^{\text {nd }}$ edition. Lviv: Payis, 2008.

Slavyanskiy assotsiativnyiy slovar: russkiy, belorusskiy, bolgarskiy, ukrainskiy [Slavonic Associative Dictionary: Russian, Belorussian, Bulgarian and Ukrainian languages]. (2004). N. Ufimtseva, Ed. Moscow.

Slovar assotsiativnyih norm russkogo yazyika. Pryamoy [Associative guide of Russian language. Direct] (1973). A. Leontyev, Ed. Moscow.

Cherkasova, G. (2008). Russkiy Sopostavitelnyi Assotsiativnyi Slovar [Russian comparative associative dictionary]. Moscow: Institute of Linguistics of the Russian Academy of Sciences. 